\title{
The development paired cards using problem based learning on student competency
}

\author{
Ramadhani Putri Lestari ${ }^{1,}{ }^{*}$, Marini Damanik ${ }^{2}$ and Agus Kembaren ${ }^{2}$ \\ 'Chemistry Education Study Program, Postgraduate, Medan State University, Medan 2022l, Indonesia \\ ${ }^{2}$ Department of Chemistry, Medan State University, Medan 20221, Indonesia
}

${ }^{*}$ Corresponding author: (RPLS), putriramadhani813@gmail.com

DOI: 10.24114/jpkim.v1li3.15738

Received: 11 September 2019; Accepted: 29 November 2019

Abstract:

This study discusses development of paired cards using problem based learning model on learning outcomes and students critical thinking skills on the oxidation reduction reactions. This study aims to find out learning outcomes and critical thinking students who taught with problem based learning model using paired cards. The populations were all students of class X MIA in High School, which consists of eight classes with a total number of students 296 students. The sample was taken by random sampling techniques is experimental class and control class. Students in experimental class were taught using problem based learning model, while control class were taught using direct instruction model. The results showed that average for the student learning outcomes 75.16 for experimental class and 70.63 for control class. The average students critical thinking skills were $40.17 \%$ for experimental class and $31.49 \%$ for control class. The student learning outcomes and critical thinking skills use problem based learning models with paired card was higher than the direct instruction model on the reduction oxidation reaction. There is a positive correlation between learning outcomes and students critical thinking skills.

Keywords: Paired cards; problem based learning; oxidation reduction reaction

\section{Introduction}

Chemistry is a subject that is not just a theory but is closely related to daily life. Learning that is connected with concepts and examples in daily life will be easily remembered by students (Wardani et al. 2016). In learning chemistry, always dealing with problems and solving them so that it is said to be difficult subject matter (Dewi and Handayani, 2015).

Oxidation reduction reaction is one of topic for chemistry class $X$ high school which is considered difficult. Characteristics of this topic require the ability to understand, memorize, calculate and analyze and the activity of students to practice in order to understand concept (Purnamawati et al. 2014). The difficulty of students in learning concepts can lead to conceptual errors. It starts from the sub-section on the development of oxidation reduction notions to determine the number of students experiencing difficulties (Rudiyanto et al. 2013). Oxidation reduction reaction topic has delivered to student by problem-based learning model. Problem based learning (PBL) is a learning model that requires students to understand a concept of learning through situations and problems with problem solving approach that presented at the beginning of learning (Wasonowatiet al. 2014; Silaban and Simangunsong, 2015; Purba et al. 2018). On the other hand, problem based learning model need critical thinking skills which students can be trained to explore, inquiry, discover and solve problems (Widana et al. 2018; Panggabean et al. 2019).

Thinking critical when students try to analyze, argument and problem carefully, look for 
evidence and appropriate solutions, and produce solid conclusions to believe and do something. The more feedback the teacher makes to the student, the more the students ability to ask, argue and answer questions from the teacher will develop. The more often students are trained to think critically during the learning process in class, the more students knowledge and experience in solving problems inside and outside the classroom will also increase (Lukitasari, 2013; Silaban, 2017).

Using learning media in the learning process can improve the understanding of the concept of science. The student learning achievement in the problem based learning model equipped with learning media in the form of paired cards. The learning media of card in the classroom should be innovative, creative, and fun so that it is expected to improve student's understanding of the topic. This media is gave students the opportunity to construct knowledge by discovering and experiencing them self. Card media help students to draw conclusions from an event. Thus, the card media will guide students to think critically about the problems presented and draw conclusions about the relationship between the problems and the material presented (Sariwati et al. 2015; Harefa et al. 2019).

The research which conducted by Fajariah (2015) with the title "the effect of deeper learning cycle models combined with $\mathrm{pbl}$ on oxidation reduction reaction material on critical thinking skills" accessed by calculating the average variable of understanding the reduction - oxidation reaction. The student critical thinking skill in experimental class was 72,448 . Compared to the student in class that has critical thinking ability score is 82.433 . The score of student's critical thinking skills are high. It can be concluded that the understanding of the reduction - oxidation material is moderate, whereas from the calculation of the average. Another study conducted by Sariwati et al. (2015) with the title, "Efforts to Improve Critical Thinking Ability and Student Learning Achievement with the Problem Solving Model Equipped with Smart Card Media" gained high critical thinking ability was $62 \%$ increased to $79 \%$. The student learning achievement aspects of knowledge $59 \%$ increased to $76 \%$. The conclusion of this study showed not only critical thinking skills but also student learning achievement was increase.

\section{Methods}

This research was conducted in Binjai State High School 2 from February - April 2017. Populations were all students of class $X$ which consisted of 8 classes with a total of 296 students. The samples in this study were class X MIA-6 and X MIA-7. Sampling is carried out by simple random sampling technique.

Data collection using cognitive domain test instruments as many as 20 multiple choice questions. Meanwhile, non-test instruments are observation sheets that assess student skills which contain aspects of critical thinking. The observation sheet for assessing student attitudes is used to measure critical thinking during the learning process. The instrument used validity test with the Product Moment formula, reliability test with K-R.21) formula, different power, and difficulty level. Research Preparation Phase observations at school, preparation of research proposals, approval research proposal, test the questions used by: validating students by calculating: validation, reliability, difficulty, differentiation. Next, maintain research permit, consult with the head of the school where the research is carried out with a research permit, consultation with chemistry teacher in class X MIA High School, developed learning material, developed student learning evaluations.

On Stage of Research has randomly specified two classes of X MIA classes High School. Randomly taken one roll of paper and opened, for example the first one taken is class X MIA 6, this class is treated using problem based learning model with paired cards. In the same way it is done to determine the second class (class $X$ MIA 7) which will be treated with the Direct 
Instruction model. Next, conducted pre-test ( $\mathrm{Tl}$ ) of the two sample classes, aiming to test the homogeneity and normality of the two sample groups, also to find out an overview of the students' initial abilities before being given different treatment about the material to be discussed. Give treatment $(X)$ given Problem Based Learning with card media in pairs in the experimental class, and treatment $(\mathrm{Y})$ is given Direct Instruction learning in the control class). Observers doing assessment of students critical thinking skills. During the research process, it will be maintained so that the conditions of all groups remain the same, for example the teacher who teaches, the book used, the length of teaching time, etc. except one thing, namely the difference in treatment in each class according has been determined. After the learning process/ giving treatment in each class is complete, and posttest to determine the value of student learning outcomes.

Final Stage of Research is the pre-test and post-test score/ value data are tabulated then calculate the difference in learning outcomes obtained in the experimental and control classes before and after pre-test and post-test, testing the analysis of statistical data on normality tests and data homogeneity tests Calculate the average (mean) value of learning outcomes and critical thinking skills obtained in each class. Next, comparing changes in the increase/ decrease in value obtained in each experiment class. Applying a suitable statistical test in this study using the right-t-test and correlation test and draw research conclusions.

Data analysis techniques consist of normality test, homogeneity test, and hypothesis test. Normality test is used to distinguish statistical data which normally distributed or not. The normality test used in this study is the chi-square test. Homogeneity test is used to test whether or not homogeneous sample variance. Hypothesis testing done using the one-part $t$ test, namely the t-test of the right part. The right-hand test is used when the alternative hypothesis reads "bigger", above (>). Correlation analysis is used to measure how closely the relationship between the variables. The strength of the relationship between variable $X$ and $Y$ variable is measured by a value called the Correlation Coefficient ("r") or symbolized by $\rho$ (rho). The magnitude of the correlation coefficient ranges from -1 and +1 or denoted by $-1<r<+1$.The research design used in this study was the pretest-posttest control group design which showed on Table 1.

Table 1

Research design

\begin{tabular}{llll}
\hline Group & Pretest & Treatment & Posttest \\
\hline Experiment & $\mathrm{T}_{1}$ & $\mathrm{X}$ & $\mathrm{T}_{2}$ \\
control & $\mathrm{T}_{1}$ & $\mathrm{Y}$ & $\mathrm{T}_{2}$ \\
\hline
\end{tabular}

$T_{l}$ :pre-test, $T_{2}$ : post-test, $X_{1}$ :the problem based learning model uses paired card,

$X_{2}$ : treatment with direct instruction models

\section{Results}

Based on the calculation results obtained statistical data on student learning outcomes in the control class and experimental class which are summarized in the table descriptive statistics on student learning outcomes in the control class and experimental class in Table 2.

Table 2

Learning outcomes in the control class and experimental classl

\begin{tabular}{llll}
\hline Class & Average Pre-test & Average Post-test & Average Skill \\
\hline Experiment & 32,19 & 75,16 & 40,17 \\
Control & 26,56 & 70,63 & 31,49 \\
\hline
\end{tabular}


From the Table 2, it can be seen the average learning outcomes between the two classes given the different treatments. Before the treatment the two samples were give pretest. The average pretest of control class $=26.56$ and experimental class $=32.19$. Then, the different treatment was given in both samples. The control class was taught the Direct Instruction model and post-test were given. The post-test average $=70.63$. While, the experimental class was taught by problem based learning model and post-test was obtained, post-test average $=75.16$. So it can be concluded that experimental class learning outcomes are higher than control class. The value of learning outcomes can be seen in Fig 1 . The value of the attitude of critical thinking skills of students in control class with the experimental class, can be seen in Fig 2.

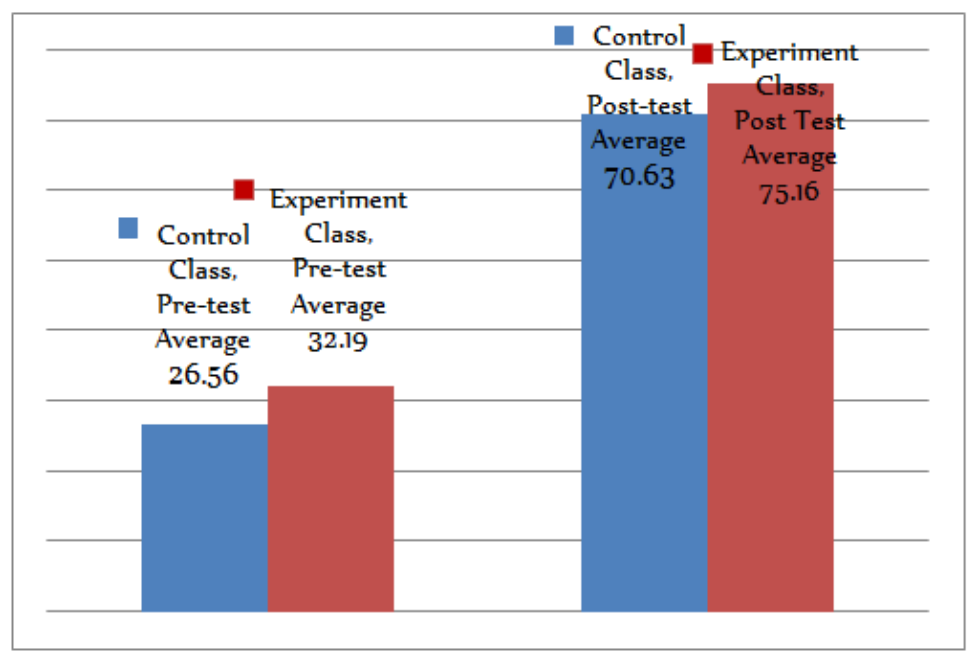

Fig 1. Learning outcomes diagram

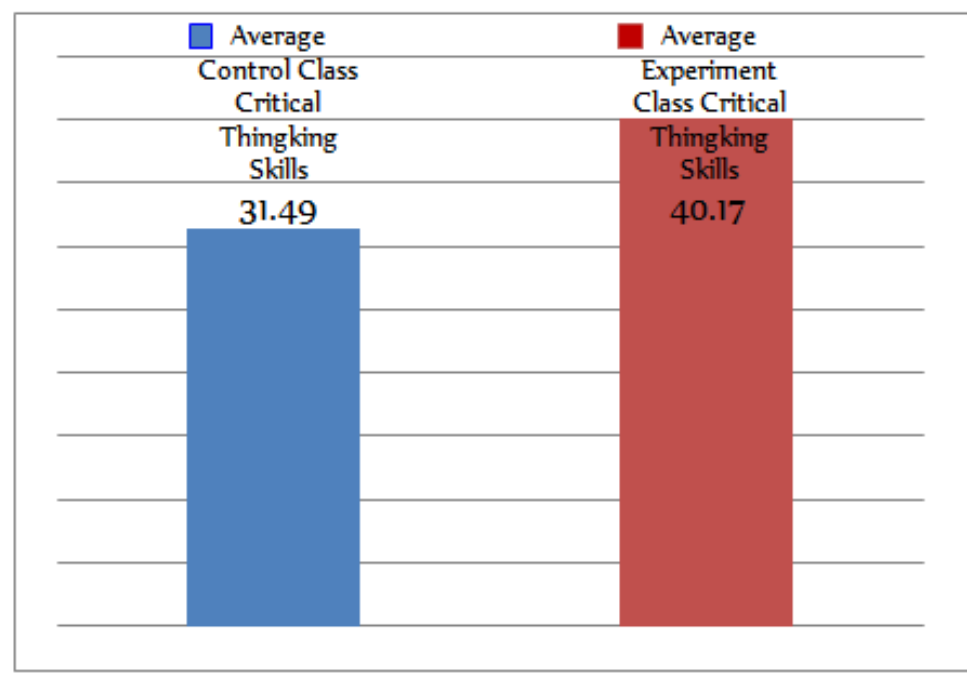

Fig 2. Critical thinking skills diagram

From the diagram above it can be seen that the average score of student critical thinking skills in the two samples is different. The control class treated with the Direct Instruction model gained an average of critical thinking skills of 31.49 and experimental class was treated with Problem Based Learning model obtaining an average critical thinking ability of 40.17. So, the critical thinking ability of students in the experimental class is higher than the control class. The hypothesis test on learning outcomes, testing criteria if $t$ count $>t$ table then reject $(\mathrm{Ho})$, so that $(\mathrm{Ha})$ is accepted. Data from hypothesis testing can be seen in Table 3. 
Table 3

Test hypothesis on learning outcomes

\begin{tabular}{|c|c|c|c|c|c|}
\hline Class & & $S^{2}$ & $t_{\text {hitung }}$ & $\mathbf{t}_{\text {tabel }}$ & Note \\
\hline Control & 70,63 & 78,63 & \multirow{2}{*}{1,986} & \multirow{2}{*}{1,672} & \multirow{2}{*}{$\begin{array}{c}\text { Reject Ho, so Ha is } \\
\text { accepted }\end{array}$} \\
\hline Experiment & 75,16 & 92,72 & & & \\
\hline
\end{tabular}

The data distribution, $\mathrm{t}$ obtained interpolation table $=1.672$. While, $\mathrm{t}_{\text {count }}=1.986$ so the price of $t_{\text {count }}>t_{\text {table, }}$, then $\mathrm{Ho}$ is rejected and $\mathrm{Ha}$ is accepted. The student learning outcomes using the Problem Based Learning model with paired media cards is higher than the Direct Instruction model on the subject of reduction oxidation reactions. The testing of the hypothesis of students critical thinking skills criteria if $t_{\text {count }}>t_{\text {table }}$ then $(\mathrm{Ho})$ is rejected and (Ha) is accepted. Data from hypothesis testing can be seen in Table 4 .

Table 4

Test the hypothesis of students critical thinking skills

\begin{tabular}{|c|c|c|c|c|c|}
\hline Class & & $\mathrm{S}^{2}$ & $t_{\text {count }}$ & $t_{\text {table }}$ & Note \\
\hline Control & 37,20 & 132,82 & \multirow{2}{*}{1,749} & \multirow{2}{*}{1,672} & \multirow{2}{*}{$\begin{array}{c}\text { Reject Ho, so Ha is } \\
\text { accepted }\end{array}$} \\
\hline Experiment & 42,22 & 156,86 & & & \\
\hline
\end{tabular}

The data distribution $\mathrm{t}$ obtained interpolation table $=1.672$ while based on the calculation obtained $t_{\text {count }}=1.986$ so that the price of $t_{\text {count }}>t_{\text {table, }}$, then Ho is rejected and Ha is accepted. It can be concluded that students' critical thinking abilities using the Problem Based Learning model with paired media cards are higher than ability critical thinking students who use the Direct Instruction model on the subject of reduction oxidation reactions. The correlation between learning outcomes and students' critical thinking skills. While, the testing criteria if $r_{\text {count }}>r_{\text {table }}$ then $(\mathrm{Ho})$ is rejected and $(\mathrm{Ha})$ is accepted which means the correlation coefficient tested is significant seen in Table 5 .

Table 5

Test the correlation between learning outcomes and students critical thinking skills

\begin{tabular}{llcc}
\hline \multicolumn{1}{c}{ Class Data } & $\mathbf{r}_{\text {count }}$ & $\mathbf{r}_{\text {table }}$ & Note \\
\hline$\Sigma \mathrm{X}=2405$ & & & \\
$\Sigma \mathrm{X} 2=183625$ & & & \\
$\Sigma \mathrm{Y}=1285,33$ & & & Ha is \\
$\Sigma \mathrm{Y} 2=$ & 0,657 & 0,349 & accepted \\
58281,5069 & & & \\
$\sum \mathrm{XY}=99701,3$ & & & \\
$\mathrm{~N}=32$ & & & \\
\hline
\end{tabular}

Table 5 shows $r_{\text {count }}=0.657$ while $r_{\text {table }}$ at $\alpha=0.05(\mathrm{~N}=32)$ is equal to 0.349 . Because $r_{\text {count }}>r_{\text {table }}$ then $\mathrm{Ho}$ is rejected which means $\mathrm{Ha}$ is accepted. It means that there is a positive and significant correlation between learning outcomes and critical thinking skills of students using the Problem Based Learning model with paired media cards on the subject of oxidation reduction reactions. Based on the calculated correlation coefficient of 0.657 , the meaning of the correlation is high. 


\section{Discussion}

The experimental class that was taught using the problem based learning model before being given treatment, it was found that the average student learning outcomes were 32.19. The problem based learning model using paired media cards obtained average scores. The average student learning outcomes are 75.16. In the control class, that was taught by the Direct Instruction model, before being given treatment it was found that the average value of student learning outcomes was 26.56. After using the Direct Instruction model, the average value of student learning outcomes was obtained at 70.63 .

The student critical thinking skills obtained an average value of critical thinking skills in the experimental class that was taught using the Problem Based Learning model obtained at 42.22 with a fairly critical category. While, the control class that was taught using the Direct Instruction model obtained an average value the average critical thinking skills 37.20 with a fairly critical category. Although the category is the same, which is quite critical, the experimental class taught using the Problem Based Learning model is still superior to the control class that is taught using the Direct Instruction model. This relates to the use of the learning models that are used by students challenged to be able to solve problems by investigating the problem together in groups. Thus, the student abilities cognitive, affective and psychomotor can develop especially in critical thinking skills. On the other hand, the student knowledge will increase so that the learning outcomes obtain by students is high.

Sariwati et al. (2015) with the title, "Efforts to improve critical thinking ability and student learning achievement with the problem solving model equipped with smart card media" gained high critical thinking ability was $62 \%$ increased to $79 \%$. The student learning achievement aspects of knowledge $59 \%$ increased to $76 \%$. The conclusion of this study showed not only critical thinking skills but also student learning achievement was increase. Fajariah (2015) with the title "The effect of deeper learning cycle models combined with PBL on oxidation reduction reaction material on critical thinking skills" accessed by calculating the average variable of understanding the reduction-oxidation reaction. The students critical thinking skill in experimental class was 72,448 . Compared to the student in class that has critical thinking ability score is 82.433. The score of student's critical thinking skills are high. It can be concluded that the understanding of the reduction - oxidation material is moderate, whereas from the calculation average.

Based on the learning outcome data and students critical thinking skills taught with the Problem Based Learning model using paired card media on the subject of oxidation reduction reactions, the correlation coefficient $(r)$ of 0.657 was obtained, while the $r_{\text {table }}$ at $\alpha=0.05(\mathrm{~N}=$ 32) was 0.349 Because $r_{\text {count }}>r_{\text {table }}$ then Ho is rejected which means Ha is accepted. There is a significant relationship between learning outcomes and critical thinking skills of students using the Problem Based Learning model with paired media cards on the subject of oxidation reduction reactions. The meaning of the correlation coefficient $r=0.657$ including high correlation.

\section{Conclusion}

The conclusions obtained are student learning outcomes and critical thinking skill using paired cards based problem based learning on reduction oxidation reaction in experiment class higher than control class. The average the student learning outcomes 75.16 for experimental class and 70.63 for control class. While, average students critical thinking skills were $40.17 \%$ for experimental class and $31.49 \%$ for control class. Based on calculated correlation coefficient obtained 0.657, meaning correlation is high. There is a positive correlation between student learning outcomes and critical thinking skills. 


\section{Acknowledgments}

The authors thank to principal of High School 2 Binjai and chemistry teacher for allowing do this research.

\section{References}

Dewi, C. A., \& Handayani, T. F. (2015). Pengembangan modul kimia berbasis problem based research (pbr) pada materi larutan elektrolit dan nonelektrolit. Jurnal Pengkajian Ilmu dan Pembelajaran Matematika dan IPA “PRISMA SAINS, 3(2), 369-372.

Fajariah, I.R. (2015). Pengaruh model pembelajaran deeper learning cycle dipadukan pbl pada materi reaksi redoks terhadap kemampuan berpikir kritis di MA NU o3 Sunan Katong. Semarang. UINWalisongo.

Harefa, N., Silalahi, N. F. D., Sormin, E., Purba, L. S. L., \& Sumiyati, S. (2019). The difference of students' learning outcomes with project based learning using handout and sway Microsoft 365. Jurnal Pendidikan Kimia, 11(2), 24-30, doi: 10.24114/jpkim.v1li2.14459

Lukitasari, D.R. (2013). Upaya meningkatkan kemampuan berpikir kritis siswa melalui model pembelajaran berbasis masalah dengan berbantuan film sebagai sumber belajar pada pokok bahasan sikap pantang menyerah dan ulet kelas X PM SMK N I Batang. Semarang. Universitas Negeri Semarang.

Panggabean, F. T. M., Silaban, S., \& Simorangkir, M. (2019). Implementation of virtual lab media using problem based learning models to increase students learning achievement based STIFI and learning style test. Proceedings AISTSSE, doi: 10.4108/eai.18-10-2018.2287391

Pratiwi, Y., Redjeki, T., \& Masykuri, M. (2014). Pelaksanaan model pembelajaran problem based learning (pbl) pada materi redoks kelas $x$ sma negeri 5 Surakarta tahun pelajaran 2013/2014. Jurnal Pendidikan Kimia, 3(3), 40-48.

Purba, D. N., Damanik, M., Silaban, S., \& Simatupang, L. (2018). The difference of student's activities and learning outcome with problem based learning using macromedia flash and handout. Jurnal Pendidikan Kimia, 10(3), 403-408, doi: 10.24114/jpkim.v10i3.12704

Purnamawati, H., Ashadi, A., \& Susilowati, E. (2014). Pengaruh model pembelajaran kooperatif tipe teams games tournament (tgt) dengan media kartu dan ular tangga ditinjau dari kemampuan analisis siswa terhadap prestasi belajar siswa pada materi pokok reaksi redoks kelas $\mathrm{x}$ semester 2 sma muh 1 karanganyar. Jurnal Pendidikan Kimia, 3(4), 100-108.

Rudiyanto., Oktavia, S., \& Darsono, S. (2013). Pengaruh model pembelajaran think pair share (tps) terhadap aktivitas belajar dan prestasi belajar siswa kelas x sman 6 kota malang tahun pelajaran 2012-2013 pada materi reaksi redoks. Malang: Universitas Negeri Malang.

Sariwati, L. N. A., Utami, B., \& Masykuri, M. (2015). Upaya meningkatkan kemampuan berpikir kritis dan prestasi belajar siswa dengan model problem solving dilengkapi media kartu pintar pada materi hukum dasar kimia kelas $\mathrm{x}$ mia 3 semester ii sma al islam 1 surakarta tahun pelajaran 2014/2015. Jurnal Pendidikan Kimia, 4(4), 123-131.

Silaban, S. (2017). Dasar-dasar pendidikan matematika dan ilmu pengetahuan alam. Medan: Harapan Cerdas Publisher.

Silaban, S., \& Simangunsong, N. S. D. (2015). Pengaruh model pembelajaran Contextual Teaching and Learning $(\mathrm{CTL})$ terhadap hasil belajar siswa pada pokok bahasan sistem koloid. Jurnal Pendidikan Kimia, $7(1)$.

Widana, l. W., Parwata, I. M. Y., Parmithi, N. N., Jayantika, I. G. A. T., Sukendra, K., \& Sumandya, l. W. (2018). Higher order thinking skills assessment towards critical thinking on mathematics lesson. International Journal of Social Sciences and Humanities, 2(1), 24-32, doi: 10.29332/ijssh.v2n1.74

Wardani, S., Nurhayati, S., \& Safitri, A. (2016). The effectiveness of the guided inquiry learning module towards students' character and concept understanding. International Journal of Science and Research (IJSR), 5(6), 1589-1594, doi: 10.21275/v5i6.NOV164512

Wasonowati, R. R. T., Redjeki, T., \& Ariani, S. R. D. (2014). Penerapan model problem based learning (pbl) pada pembelajaran hukum-hukum dasar kimia ditinjau dari aktivitas dan hasil belajar siswa kelas x ipa sma negeri 2 surakarta tahun pelajaran 2013/2014. Jurnal Pendidikan Kimia, 3(3), 66-75. 